\title{
EKOSISTEM KEHIDUPAN YANG BERKELANJUTAN DENGAN SISTEM APUNG
}

\author{
Christie Angelina1), Tony Winata2) \\ 1)Program Studi S1 Arsitektur, Fakultas Teknik, Universitas Tarumanagara, agtchristie@gmail.com \\ 2)Program Studi S1 Arsitektur, Fakultas Teknik, Universitas Tarumanagara, tonywinata@ft.untar.ac.id
}

Masuk: 04-07-2021, revisi: 14-08-2021, diterima untuk diterbitkan: 23-10-2021

\begin{abstract}
Abstrak
Baraya - Sustainable Living Ecosystem adalah sebuah proyek untuk mempertahankan ruang hijau dan juga lahan persawahan-perkebunan sebagai sumber pangan dengan menyediakan suatu wadah baru bagi ekosistem. Proyek ini didasari atas krisis lahan, pangan, dan juga ekosistem dan bagaimana Kota Jakarta mampu bertahan di masa depan menghadapi permasalahan yang ada. Dengan kondisi lahan di Indonesia yang 70\%nya merupakan air, dapat dijadikan sebagai suatu wadah baru ekosistem yang beradaptasi dan sustainable. Memiliki kehidupan di perairan, tentunya arsitektur apung dirancang dengan penggunaan material dan juga struktur yang mampu menahan kondisi laut. Proyek ini bersifat modular dan dapat diperluas sesuai keubutuhan dari masyarakat dan juga ekosistem lainnya sehingga kehadirannya dapat memberi dampak positif bagi sekitar.
\end{abstract}

Kata kunci: arsitektur apung; ekosistem; modularitas; keberlanjutan

\begin{abstract}
Baraya - Sustainable Living Ecosystem is a project to maintain green space and also rice fields as a source of food by providing a new container for the ecosystem. This project is based on the land, food and ecosystem crisis and how the City of Jakarta will be able to survive in the future in facing the existing problems. With $70 \%$ of the land in Indonesia being water, it can be used as a new container for adaptable and sustainable ecosystems. Having aquatic life, of course the floating architecture is designed with the use of materials and structures that can withstand sea conditions. This project is modular and can be extended to the needs of the community and other ecosystems so that its presence can have a positive impact on the surroundings.
\end{abstract}

Keywords: ecosystem; floating architecture; modularity; sustainability

\section{PENDAHULUAN}

\section{Latar Belakang}

Melihat kondisi bumi saat ini terutama perkotaan yang perlu banyak dibenahi ekosistemnya, bangunan-bangunan sudah memenuhi hampir seluruh permukaan yang ada. Hanya demi kepentingan manusia dan keuntungan semata tanpa memikirkan dampaknya terhadap kondisi kota dikemudian hari, pembangunan terus berjalan dan kota semakin krisis. Krisis akan lahan dan juga makanan akibat dari perkembangan kota yang meningkatkan populasi manusia di perkotaan yang pada akhirnya berdampak pada kualitas makhluk hidup yang ada. Jika hal ini berlangsung terus menerus, keberlanjutan masa depan akan terancam. Dengan demikian, perlu ada perubahan dan proses belajar untuk hidup lebih berkelanjutan. Di sini, peran arsitek sangat diperlukan. Pasalnya, arsitek, memiliki kesempatan untuk melakukan perubahan yang dapat berdampak drastis sehingga mengubah dunia menjadi lebih berkelanjutan. Gerakan menuju desain sosial hampir setengah dari populasi dunia tidak memiliki akses terhadap air minum bersih. Di sisi lain, permukaan laut diperkirakan naik hingga lima kali pada tahun 2100, menempatkan beberapa kota-kota pesisir yang padat penduduk di bawah air. 
Dua skenario ini disebabkan karena penduduk dunia mengonsumsi terlalu banyak sumber daya dengan kecepatan tak terkendali. Pemanfaatan teknologi mengkonsumsi sumber daya energi dan penyebaran polusi dari sumber air dunia telah memaksa desain arsitektur berteknologi untuk membantu memperlambat laju tersebut. Disinilah kita berperan dalam merangkul teknologi dalam merancang. Pada skala lingkungan, bertujuan untuk menghasilkan pekerjaan yang berkelanjutan dan kontribusi warga negara yang etis dan bertanggung jawab terhadap ekonomi kota. Ini juga berupaya untuk menciptakan kesadaran kolektif dengan menggabungkan penduduk dan mitra lokal di sekitar tujuan bersama.

Dalam kasus ini, lahan hijau yang banyak diambil juga kebanyakan merupakan lahan persawahan yang masih tersisa di perkotaan terutama di Jakarta yang merupakan pusat ekonomi, bisnis, budaya, dan aktivitas di Indonesia. Merupakan satu-satunya sumber pasokan yang tidak seberapa jumlahnya untuk kebutuhan hidup masyarakat di Jakarta, masih mengandalkan pasokan kebutuh dari luar daerah. Dengan penambahan suatu sumber pangan diperkotaan ini mengurangi gas esmisi dan menjadi sebuah kunci untuk kota yang lebih sehat, bersih, dan selfsustainable, serta meningkatkan kualitas makhluk hidupnya.Sangatlah sulit untuk mempertahankan ruang hijau dan juga lahan persawahan di Ibukota ini, jadi disini bagaimana kita berpikir untuk kedepannya bagaimana tetap mempertahankan fungsi tersebut dengan lahan yang terbatas. Di Indonesia sendiri $70 \%$ wilayahnya merupakan air, bisa menjadi suatu potensi untuk masa depan sebagai suatu tempat ekosistem baru. Masa depan kita adalah lautan.

\section{Rumusan Permasalahan}

Berdasarkan Identifikasi Masalah diatas, maka Rumusan masalah yang muncul adalah bagaimana menciptakan sebuah ruang baru dan mengatasi alih fungsi lahan pertanian? bagaimanakah arsitektur dapat mengambil peran dalam membangun relasi antar manusia, alam, dan juga makhluk hidup lainnya untuk tetap menjaga keseimbangan ekosistem? apakah kita dapat menggunakan sumber daya alam secara lebih efisien dengan sumber energi alternatif?

\section{Tujuan}

Berdasarkan identifikasi masalah diatas, maka tujuan dari proposal ini adalah menciptakan suatu wadah baru, di tempat yang memungkinkan terjadinya pembangunan selain daratan, yang mampu menampung kehidupan baik manusia maupun ekosistem sekitarnya sebagai alternatif dari lahan yang menipis sekaligus persiapan untuk pembangunan jangka panjang; menciptakan arsitektur dengan prinsip ekologi dan fungsi yang saling menguntungkan bagi makhluk hidup dan juga alam; memproduksi pangan untuk masyarakat secara langsung. (tanpa distribusi), meningkatkan hubungan antara produsen dan konsumen; memanfaatkan teknologi untuk menghemat penggunaan sumber daya alam dan juga dengan sumber energi alternatif

\section{KAJIAN LITERATUR}

Ekologi merupakan ilmu tentang hubungan timbal balik antara makhluk hidup dan kondisi alam sekitarnya/ lingkungannya (KBBI). Ekologi adalah cabang ilmu biologiyang mempelajari interaksi antara makhluk hidup dengan makhluk hidup lain dan juga dengan lingkungan sekitarnya. Dalam ilmu lingkungan, ekologi dijadikan sebagai ilmu dasar untuk memahami interaksi di dalam lingkungan. Dalam catatan Stanford Encyclopedia of Philsophy dijelaskan bahwa ada dua masalah penting Ketika dihadapkan dalam diskursus ekologi, yaitu: (1) Masalah Kompleksitas yaitu membicarakan masalah ekologi dihadapkan bukan hanya pada masalah yang rumit tetapi memilki kompleksitas tinggi. Kondisi rumit dan kompleks ini disebabkan karena menyangkut tentang hubungan antara manusia dengan kondisi alam yang memiliki kedinamisan dalam perubahannya (2) Masalah Keunikan yaitu sistem ekologi dianggap unik baik karena merupakan entitas historis yang bergantung, dan secara struktural 
karena kompleksitasnya. Kompleksitas dan Keunikan dari sebuah kondisi ekosistem menjadi kata kunci dalam menghasilkan kajian keruangan baru bagi bumi ini.

\section{CIVIL OR CAPITALIST?}

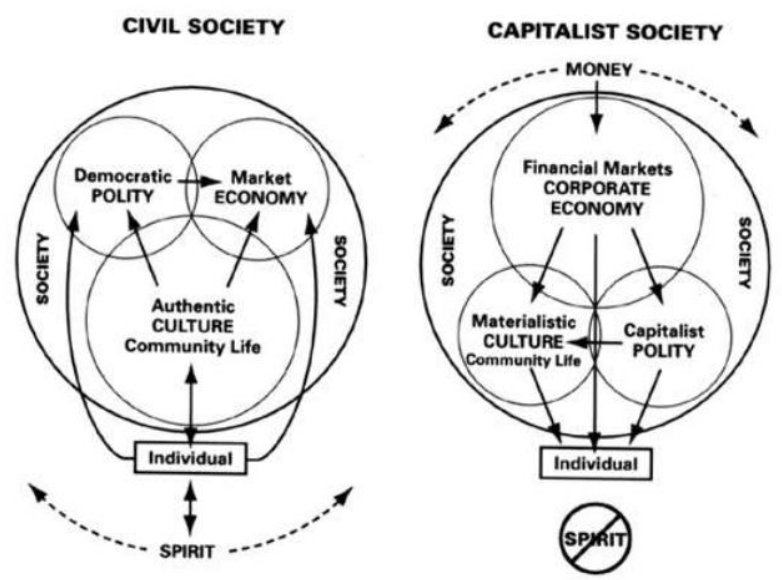

Gambar 1. David Korten's Model of Civil or Capitalist Society Sumber: medium.com

Yang kami maksud dengan ekologi adalah tubuh pengetahuan tentang ekonomi alam penyelidikan hubungan total hewan baik dengan lingkungan organik maupun anorganiknya; termasuk di atas segalanya, hubungan persahabatan dan permusuhannya dengan hewan dan tumbuhan yang bersentuhan langsung atau tidak langsung dengannya - dengan kata lain ekologi adalah studi tentang keterkaitan yang kompleks yang disebut oleh Darwin sebagai kondisi perjuangan untuk eksistensi (Ernest Haeckel, 1886 via Hall, 2019). Bagaimana arsitektur 'Melampaui' Ekologi? Jawabannya adalah kemampuan untuk melihat lingkungan binaan yang penuh dengan objek ekosistem dan bangunan yang dirancang harus sebagai 'rumah ' -'oikos' bagi manusia di bumi. Rentang keterbacaan arsitektur sebagai 'oikos' menggemakan spektrum keruangan yang mudah dipahami dalam citra dan gunanya. Kita percaya bahwa arsitektur berbicara melalui ruang dan waktu, dalam bahasa fungsional, struktural, material, formal, teknis, tipologis, dan melalui tampilan semiotik ikon, indeks serta simbol-simbol. Pada titik yang lainnya, adalah tentang bagaimana arsitektur mempengaruhi ranah publik dalam masalah sosial, budaya, politik, ekonomi dan lingkungannya.

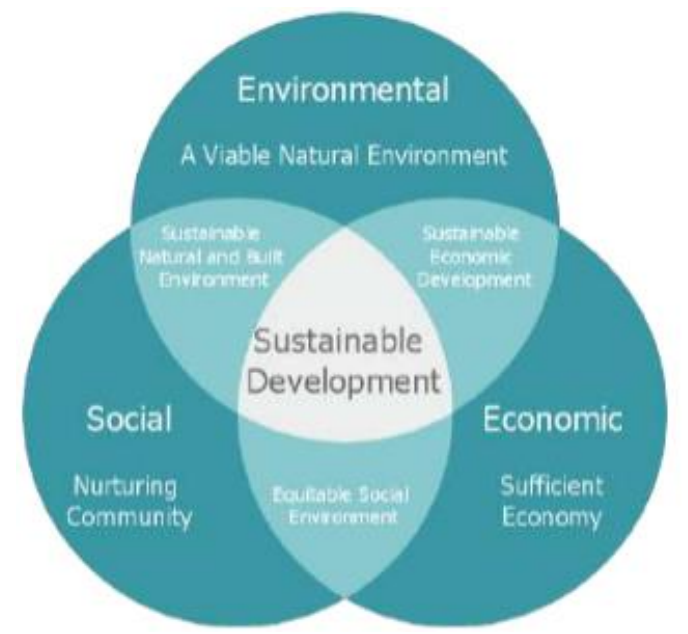

Gambar 2. Sustainable Development Connection

Sumber: esmeraldbl.com 


\section{Konstruksi Bangunan Terapung \\ Massa Bangunan}

Saat kita ingin mendesain suatu bangunan, entah bangunan itu berukuran besar ataupun kecil, berlantai banyak ataupun hanya satu lantaii, yang patutu dipertimbangkan adalah massa bangunan. Massa bangunan sendiri sangat berpengaruh dalam jati diri sebuah bangunan serta mencerminkan kegunaan bangunan itu sendiri. Dalam merencanakan sebuah bangunan terapung sendiri, perlu diperhatikan massa bangunannya. Syarat massa bangunan pada desain bangunan terapung yaitu bentuk bangunan harus simetris agar pembagian beban pada struktur apung merata dan stabil; bentuk simetri dapat berupa bangunan dengan bentuk dasar geometri; bentuk ini memang mempunyai sisi-sisi yang simetris dengan sisi yang lain; menggunakan konstruksi ringan, yaitu menggunakan material seperti kayu, cladding, alumunim, bamboo dll; sangat haram bangunan terapung menggunakan batu bata ataupun beton; penggunaan material ini bertujuan agar tidak membebani struktur apung itu sendiri; konstruksi bangunan merupakan konstruksi ikat yang dapat menahan gaya vertikal ataupun horizontal dari angin dan gelombang air

\section{Pelat Apung}

Pelat apung merupakan bagian terpenting pada bangunan ini, karena bagian ini merupakan inti utama dari struktur bangunan ini. Pelat apung perlu ditinjau bahan dan peletakannya. Pada dasarnya, pelat apung merupakan tempat melekatnya massa bangunan. Bagian dari pelat apung ini adalah lapisan penutup, rangka pelat dan pelampung. Bentuk pelat apung ini sendiri akan mempengaruhi konfigurasi pelampung yang digunakan.
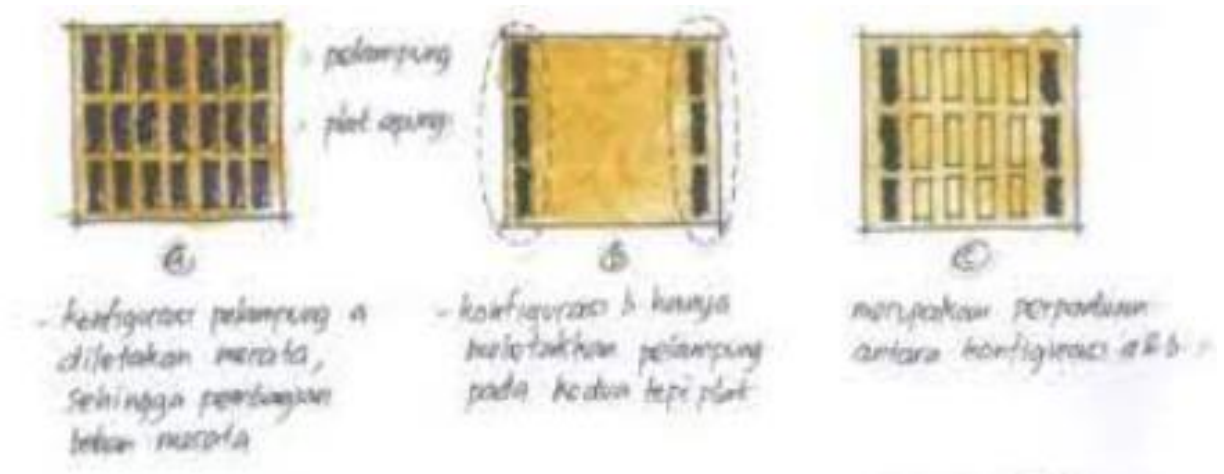

Gambar 3. Konfigurasi Pelampung

Sumber: Fachruddin Muchsin, Edi Hari Purwono, Chairil B. Amiuza - Penelitian Penginapan Terapung di Lombok, 2011

\section{Sistem Tambat}

Sistem tambat harus sangat diperhatikan pada desain struktur terapung. Pada desain bangunan ini diperlukan sebuah 177 sistem tambat yang cukup kaku dan kuat untuk membatasi pergerakan struktur yang disebabakan oleh gaya yang ada diluar bangunan, seperti angin dan ombak. Ada banyak sekali sistem penambatan yang dapat digunakan pada struktur bangunan terapung, baik sistem penambatan permanen ataupun temporer. Sistem penambatan yang dapat digunakan saat akan membangun bangunan dengan struktur terapung yaitu Attached Mooring System (sistem ini, penambatan dilakukan hanya pada salah satu bangunan, yaitu menggunakan pengikat truss. Penambatan ini dilakukan dengan menambatkan satu bagian khusus dari mooring line ke bagian struktur terapung. Penerapan system ini biasanya digunakan pada bangunan terapung dengan kondisi air yang tetap). 


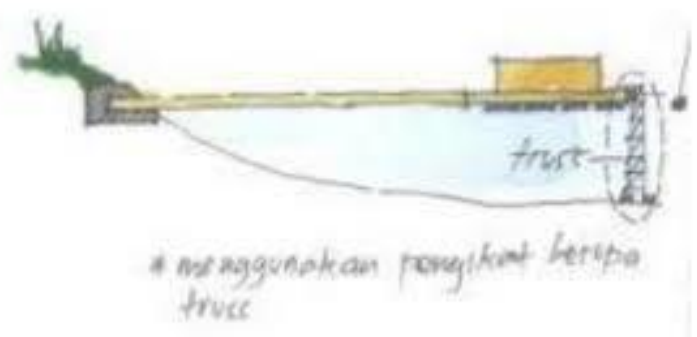

Gambar 4. Attached Mooring System

Sumber: Fachruddin Muchsin, Edi Hari Purwono, Chairil B. Amiuza - Penelitian Penginapan Terapung di Lombok, 2011

Sistem Tiang Pancang. Pada sistem ini tiang pancang digunakan untuk menjaga bangunan terapung agar tetap pada tempatnya dan tidak terombang ambing dikarenakan pasang surut air. Sistem ini telah banyak digunakan pada rumah tradisional jaman dahulu oleh nenek moyang kita).
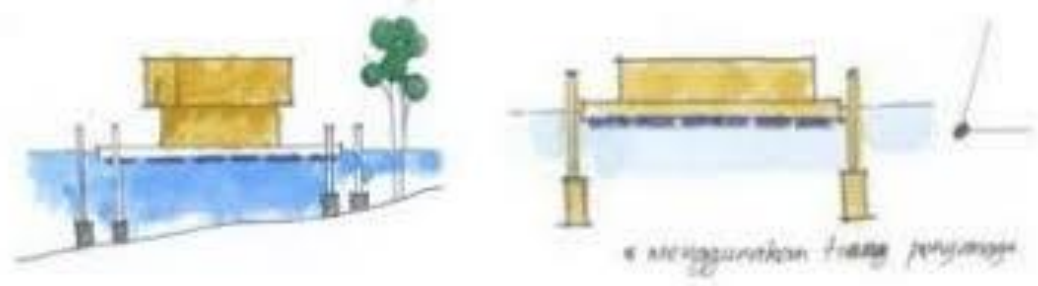

Gambar 5. Sistem Tiang Pancang

Sumber: Fachruddin Muchsin, Edi Hari Purwono, Chairil B. Amiuza - Penelitian Penginapan Terapung di Lombok, 2011

Spread Mooring System. Sistem ini merupakan sistem yang menggunakan kabel sebagai penahan struktur bangunan terapung. Kabel ini berfungsi sebagai penambat bangunan yang berada di perairan yang realtif tenang dan mempunyai arah pembebanan yang cenderung konstan. Konfigurasi kabel ini ada dua jenis yaitu menyilang dan menyebar; Disconnectable Mooring System System ini merupakan sistem temporer dan tidak selalu melekat pada bangunan; Turret Mooring System. System ini cocok digunakan dengan kondisi lingkungann yang keras, sistem ini di gabungkan dengan mooring sistem dan struktur terapung.
\end{abstract}

\title{
Sirkulasi dan Penataan Massa Bangunan
}

Pada bangunan terapung, akses bangunan juga harus dipertimbangkan dengan baik. Penataan massa di atas air dipertimbangkan berdasarkan kemudahan konstruksi dan pencapaian. Sistem sirkulasi yang digunakan juga akan mempengaruhi sistem utilitas yang ada pada bangunan. Terdapat beberapa konfigurasi penataan massa pada bangunan terapung, yaitu Linear (penataan massa linier ini merupakan pola yang paling sederhana, memiliki kemudahan dalam konstruksi, utilitas dan pencapaian bangunan. Untuk bangunan bermassa banyak dan bangunan berskala kecil, jenis penataan ini sangat sesuai); Radial (penataan radial sesuai untuk bangunan terapung dengan skala besar, misalkan sebuah kota terapung yang membutuhkan luas besar. Sistem utilitas pada penataan radial dipusatkan ke tengah, kemudian dialirkan menuju darat) 


\section{METODE}

Untuk melakukan tahap perancangan maka diperlukan data - data yang mendukung, data yang didapat bersifat kualitatif dan juga data kuantitatif. Berawal dari fenomena yang terjadi saat ini yang dirasakan dan memberi dampak pada kehidupan saat ini. Dari fenomena tersebut kemudian dilakukan observasi lingkungan yang terkait dengan tapak beserta dengan data lapangan untuk kemudian dianalisa dengan teori. Dengan tema "Beyond Ecology" ini, rancangan yang dibuat juga berdasarkan konsep melampaui ekologi dengan berbasis pada kondisi saat ini dan juga gambaran persiapan akan masa depan. Jenis penelitian kualitatif fenomenologi dapat memperhatikan dan menelaah fokus fenomena dan aspek subjektif dan perilaku bahan penelitian. Setelah itu mencari literature yang terkait dengan usulan program yang sesuai dengan fenomena yang ada dan melakukan perbandingan antara data yang sudah terkumpul dengan studi preseden. Program arsitektur pun pada akhirnya terbentuk setelah proses pendalaman akan fenomena tersebut. Dari data dan analisa melahirkan program yang diwadahi oleh arsitektur sebagai tujuan akhir untuk mengatasi fenomena yang terjadi dan meningkatkan kualitas hidup masyarakat pada lokasi yang bersangkutan.

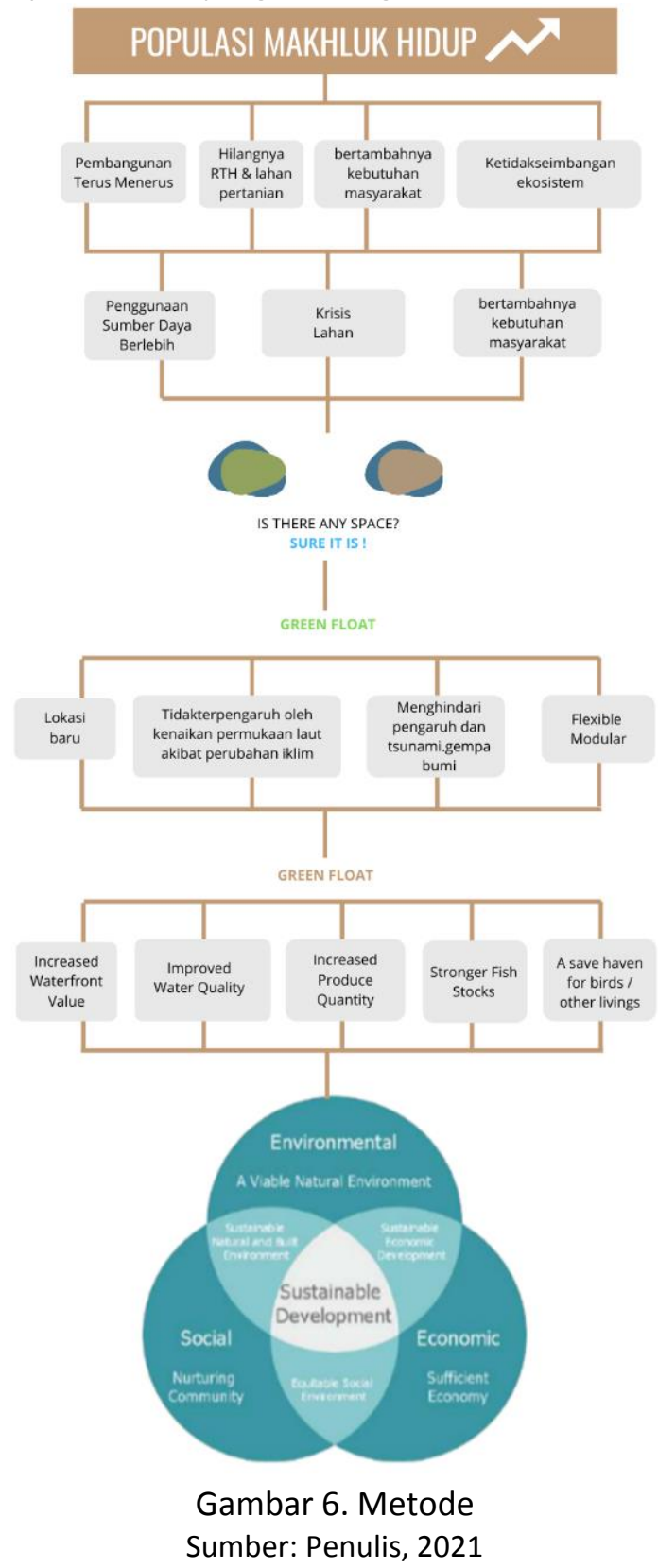


Dalam perancangannya akan diterapkan suatu arsitektur yang bersifat modular dan moveable untuk mempermudah pembangunan di tapak yang ada. Selain itu dengan sistem modular ini dapat dibangun pada area lain yang memiliki isu yang sama. Penerapan prinsip-prinsip Kevin Lynch dalam bukunya 'The Image of the City' ke dalam proyek mengimplementasikan komponen-komponen yang ada pada lokasi menjadi objek dalam prinsip Kevin Lynch.

\section{Inovasi Floating}

Lokasi baru

Untuk sebuah ibukota yang menjadi pusat populasi kesulitan dalam mengamankan lahan kosong, dimungkinkan untuk memperluas fungsi kota di melalui media air sebagai alternatif lahan.

Tidak terpengaruh oleh kenaikan permukaan laut akibat perubahan iklim.

Ada banyak negara kepulauan yang menghadapi tenggelam karena kenaikan permukaan laut akibat perubahan iklim. Kota Apung adalah salah satu cara untuk menyelamatkan daerah tersebut.

\section{Menghindari pengaruh dan tsunami, gempa bumi}

Saat tsunami mencapai pantai dangkal, tinggi gelombang meningkat. Namun, sebuah kota apung yang mengapung di lepas pantai sepenuhnya kebal dari dampak gempa bumi dan tsunami.

\section{Kota yang dapat dialihkan dan fleksibel}

Karena masalah daya tahan, banyak kota dan bangunan di darat berhenti berfungsi selama masa hidupnya. Sebaliknya, arsitektur apung dengan mudah dipindahkan dan memungkinkan lokasinya untuk dikembangkan kembali. Dengan merelokasi dan terus menggunakan material yang sustainbale, biaya siklus hidup dapat dikurangi. Selain itu, untuk memenuhi kebutuhan perluasan wilayah perkotaan, kota dapat tumbuh secara alami sebagai sel, modul, dan unit, seperti bunga teratai yang tumbuh di atas air.

\section{DATA KAWASAN}

Jakarta Utara merupakan salah satu wilayah dengan luas lahan sawah terbanyak yakni 414 hektare dari jumlah total lahan sawah tersisa di Jakarta saat ini yaitu 584,5 hektare. Luas lahan pertanian di Jakarta menurun tiap tahunnya akibat alih fungsi lahan yang diperuntukkan untuk perumahan dan komersial, dampak dari populasi yang kian meningkat di lbukota Indonesia ini. Jumlah penduduk Jakarta Utara terdapat 1.819 .958 jiwa, jumlah penduduk cilincing 430,102 jiwa.

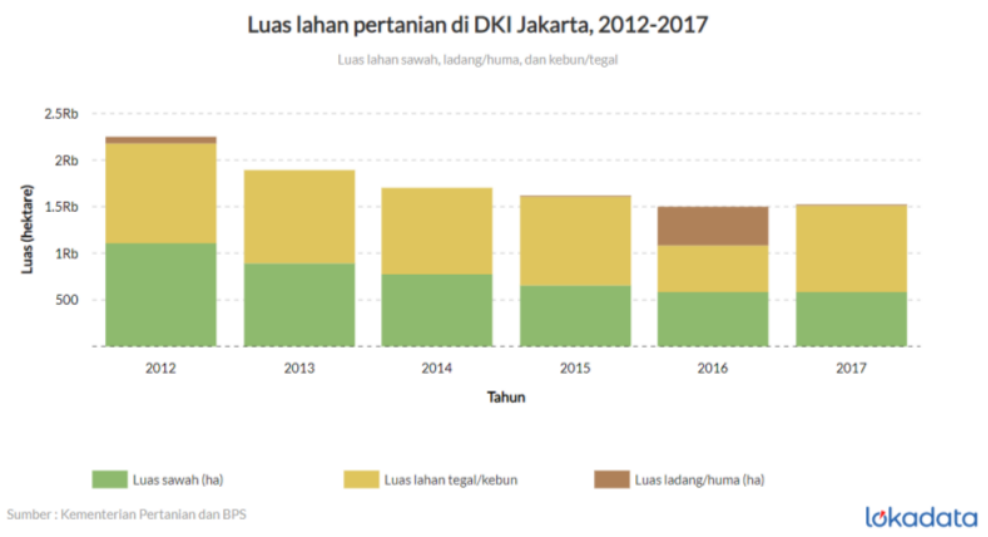

Gambar 7. Luas Lahan Pertanian DKI Jakarta Sumber: openstreetmapindonesia.id 
Letak lahan sawah tersisa sebesar 414 hektare di Jakarta Utara tersebut terletak di Kecamatan Cilincing tepatnya di Kelurahan Rorotan dan Marunda. Jadi, bisa disebut bahwa saat ini Kecamatan Cilincing menjadi sumber pangan utama yang terdapat di Jakarta

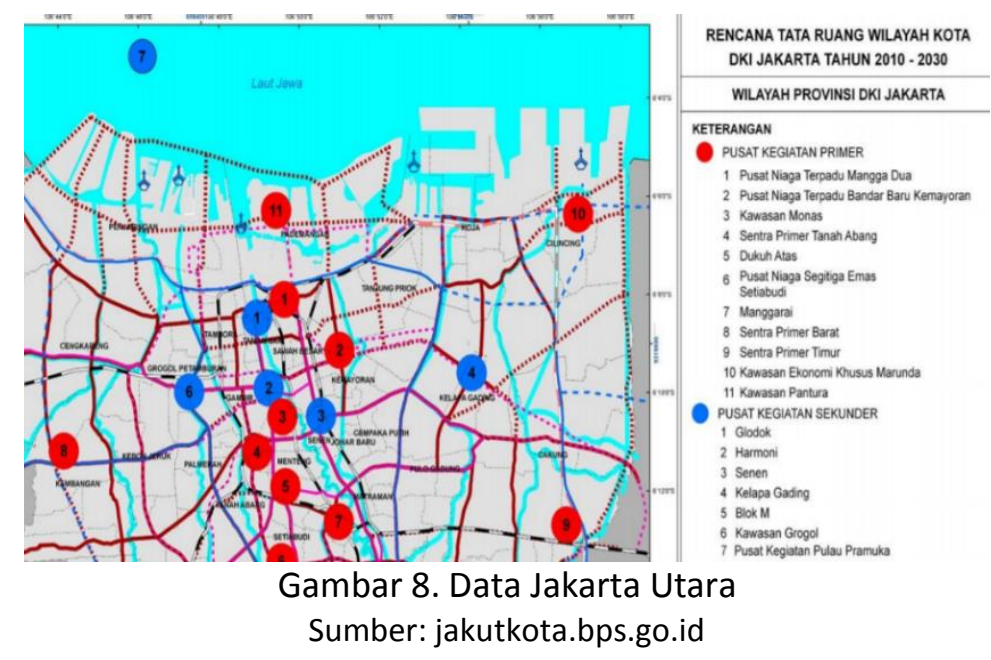

Jumlah Fasilitas Umum

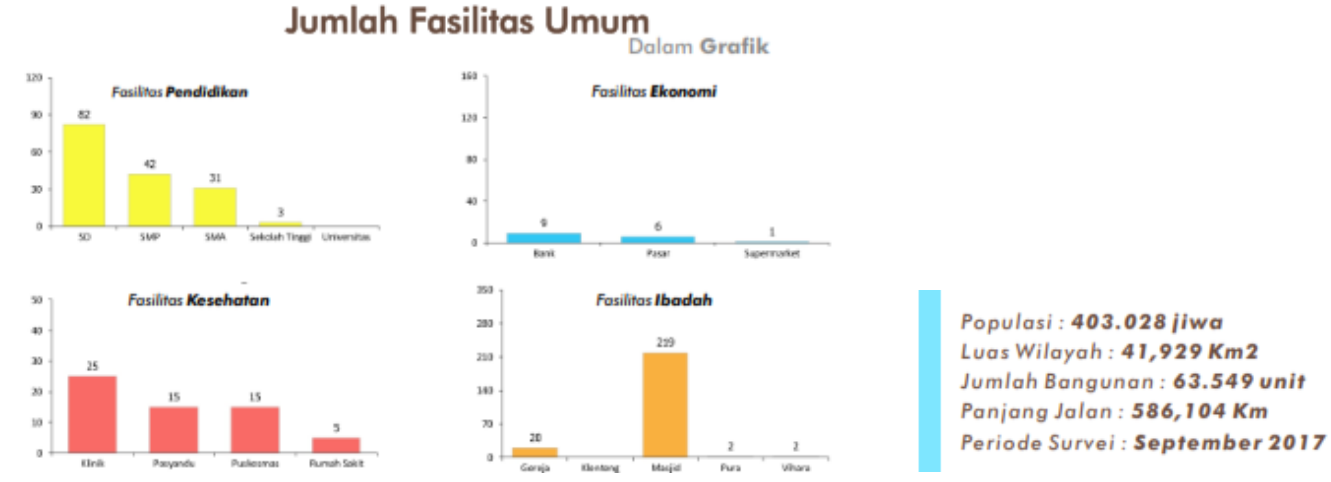

Gambar 9. Rencana Tata Ruang DKI Jakarta

Sumber: openstreetmapindonesia.id

Dari peta Rencana Tata Ruang Wilayah Kota DKI Jakarta, lokasi Cilincing berada pada nomor 10 yang termasuk dalam Wilayah Pusat Kegiatan Primer, dimana dapat menjadi sebuah potensi perkembangan menjadi produsen pangan primer sekaligus Konservasi Ekosistem di wilayah DKI Jakarta. Lokasi tapak terpilih berada di pesisir Pantai Marunda, di mana saat ini menjadi sebagi salah satu pantai publik yang menjadi destinasi wisata bagi masyarakat sekitar. Pantai Marunda juga merupakan sebuah kawasan di Jakarta Utara yang sudah berkembang menjadi daerah rusun, akan tetapi tidak adanya pengembangan pada kawasan pesisir pantai yang menyebabkan abrasi dan erosi tiap tahunnya. Hal ini sangat berdampak bagi ekosistem di area Pantai Marunda ini. Selain itu, akibat banyaknya pembangunan baru di sekitar Kelurahan Marunda dan Rorotan, muncul berbagai masalah seperti banjir yang merendam rumah-rumah warga dan juga sawah yang menjadi sebuah kekhawatiran bagi warga setempat akan gagal panen akibat banjir. Kedatangan developer ini juga mengancam mata pencaharian para petani dan juga hilangnya lahan pasokan pangan utama bagi daerah Jakarta. Dan walaupun sudah terdapat Rusun Marunda, tetapi masih banyak warga yang tinggal menetap tidak beraturan di area persawahan. Berikut merupakan zonasi wilayah pada Kecamatan Cilincing, Jakarta Utara. Tapak yang nantinya akan mengapung pada perairan, di sekitarnya terdapat persawahan, hutan mangrove, Rusunawa Marunda yang jaraknya kurang lebih berada di jangkauan $200 \mathrm{~m}$ dan juga sekitar 1 $\mathrm{km}$ dekat dengan Pelabuhan Marunda. Hal ini, menjadi sebuah peluang untuk menjadi wilayah eco-city yang dapat terintegrasi langsung dengan perumahan, taman, sekolah, rumah ibadah dan bisnis mereka. 


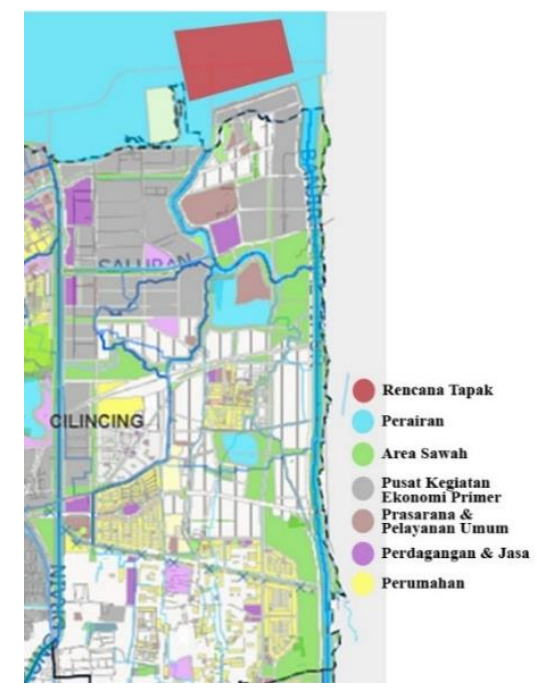

Gambar 10. Tapak dan Sekitarnya

Sumber: jakutkota.bps.go.id dan Penulis, 2021

\begin{abstract}
Aksesibilitas
Jalan Primer menuju tapak dapat diakses melalui Jalan Inspeksi Banjir Kanal Timur dan Jalan Pinggir Dermaga. Untuk menuju tapak, melewati Jalan Sekunder yaitu Jalan Akses Rusun. Lalu lintas pada kawasan ini tidak begitu padat, kebanyakan digunakan oleh warga setempat dan wisatawan dari sekitar Kelurahan Marunda. Untuk mencapai Pantai Marunda dapat digunakan kendaraan pribadi, jalan kaki, atau menggunakan Bus, terdapat terminal bus pada Sekolah Tinggi IImu Pelayaran yang berada di dekat tapak sekitar $150 \mathrm{~m}$.
\end{abstract}

\title{
5. DISKUSI DAN HASIL
}

Permasalahan akan krisis lahan yang berdampak pada pangan dan ekosistem yang ada menjadi hal yang sangat krusial bagi makhluk hidup yang ada terutama di pusat populasi yaitu di DKI Jakarta. Di Jakarta, isu ini semakin meningkat seiring dengan perkembangan jaman dan masuknya developer, lahan hijau dan persawahan yang ada terus terkikis keberadannya. Jakarta pun semakin lama semakin tenggelam, banjir dan permukaan air laut yang terus meninggi akibat tidak adanya lagi tempat penyerapan air karena mayoritas lahan tertutupi beton, hal ini berdampak pada keberlangsungan hidup makhluk hidup yang ada. Sehingga dengan adanya proyek ini diharapkan dapat mencari solusi baru dalam kedepannya bagaimana kita dapat bertahan dari krisis lahan dan juga pangan, dengan tetap mempertahankan ekosistem yang ada saat ini. Memberikan wadah baru untuk mengatasi krisis lahan dan pangan sekaligus berkegiatan dan berinteraksi sosial, serta edukasi. Ditambah dengan adanya ruang publik sebagai penunjang akan merubah gaya hidup dan persepsi orang.

Dengan adanya ruang publik, memberikan pola hidup untuk berinteraksi antar makhluk hidup dan juga alam yang ada di sekitarnya. Tidak lupa akan citra kawasan yang ada di daerah tersebut, yang merupakan sebuah identitas yang harus tetap dijaga. Mengangkat citra kawasan untuk meningkatkan kualitas kota dan masyarakat. Suatu kehadiran arsitektur di dunia, menciptakan suatu dunia yang juga akan berdampak pada karakter masyarakat sekitarnya. Oleh karena itu, apa yang ada di sekitarnya menjadi suatu pertimbangan karena berpengaruh pada apa yang akan di rancang. Ketika ada ruang publik untuk digunakan bersama, membentuk elemen pada suatu kota. Elemen ini yang menjadi karakter pada suatu tempat. Dengan mengangkat citra kawasan maka cara berbudaya suatu masyarakat akan terus diwariskan sampai ke generasi berikutnya. Dengan melakukan percobaan pada beberapa bentuk dasar, dihasilkanlah sebuah platform segilima yang mampu mengikat dan berkesinambung dengan baik antar platform nantinya. Dan, tidak dibuat sebuah 1 massa yang monumental melainkan 
dipecah menjadi unit-unit tersendiri yang bersifat modular dan dapat digabungkan, dari 1 unit menjadi 1 cluster, dan pada akhirnya mampu menjadi 1 kota yang menampung penduduk dan mampu menghidupkan kota itu sendiri dengan produksi dan juga pemanfaatan sumber daya alam yang ada di sekitarnya.

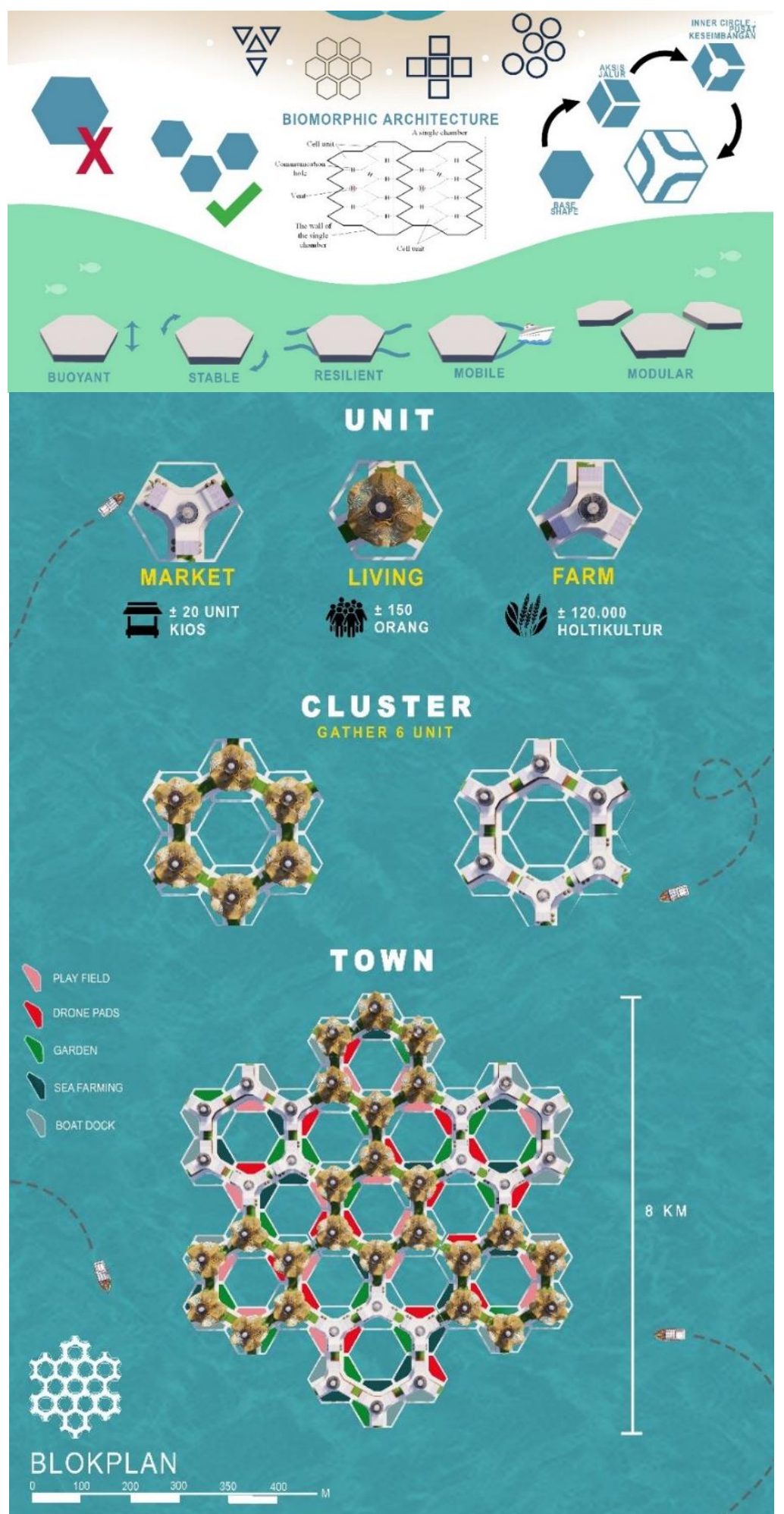

Gambar 11. Biomorphic Architecture, Unit dan Cluster

Sumber: Penulis, 2021 


\section{KESIMPULAN}

\section{Kesimpulan}

Sangatlah sulit untuk mempertahankan ruang hijau dan juga lahan persawahan di lbukota ini, jadi disini bagaimana kita berpikir untuk kedepannya bagaimana tetap mempertahankan fungsi tersebut dengan lahan yang terbatas. Di Indonesia sendiri $70 \%$ wilayahnya merupakan air, bisa menjadi suatu potensi untuk masa depan sebagai suatu tempat ekosistem baru. Masa depan kita ada di lautan. Menghadapi tantangan pertumbuhan kota saat ini, konsumsi lahan dan perubahan iklim seperti bangunan pertanian terapung dapat membantu mengurangi masalah krisis pangan, dapat meningkatkan kualitas hidup manusia dan lingkungan melalui keberlanjutan pertanian. Dengan membangun suatu wadah baru di lautan bagi manusia dan juga ekosistem lainnya, yakni terdapat tempat tinggal, produksi pangan, dan juga tempat berdagang, serta merehabilitasi ekosistem lautan melalui farm yang ada. Kedepannya proyek ini karena bersifat modular, mampu dibangun dan dipindahkan ke daerah lain yang juga membutuhkan atas isu yang sama.

\section{Saran}

Setelah melihat hasil perancangan ini, maka terdapat beberapa saran yang diperuntukan bagi beberapa elemen masyarakat. Pendekatan arsitektural untuk mengatasi permasalahan yang ada di darat, harus tetap mampu menjaga ekosistem di air dengan baik tanpa merusaknya sehingga dapat menjadi jawaban untuk mengatasi permasalahan yang ada. Perlunya juga diingatkan akan kesadaran masyarakat dalam pengunaan fasilitas yang disediakan agar tidak merusak arsitektur dan juga ekosistem sekitar. Arsitektur sebagai obyek perubahan perlu dipersiapkan untuk menjawab tantangan tersebut. Dalam hal ini, perlu ada pemikiran maju untuk merencanakan langkah-langkah perubahan di dalam bangunan tersebut sedini mungkin untuk membentuk suatu investasi yang berkelanjutan.

\section{REFERENSI}

Arief. (2003). Hutan Mangrove Fungsi dan Manfaatnya. Yogyakarta: Kanisius

Harahab, N. (2010). Penilaian Ekonomi Ekosistem Hutan Mangrove dan Aplikasinya Dalam Perencanaan Wilayah Pesisir. Yogyakarta: Graha Ilmu

Irwan, Z.D. (2003). Prinsip-prinsip Ekologi dan Organisasi Ekosistem Komunitas dan Lingkungan. Jakarta: PT Bumi Aksara.

Odum, E. (1993). Dasar-Dasar Ekologi. Yogyakarta: UGM Press.

Oldenburg, R. (1989). The Great Good Place. Cambridge: Da Capo Press.

Soemarwoto, O. (1983). Ekologi, lingkungan hidup, dan pembangunan. Jakarta: Djambatan Supriharyono. (2007). Konservasi Ekosistem Sumber Daya Hayati. Yogyakarta: Pustaka Pelajar Aryodamar, (2020), diunduh 9 Februari 2021, https://www.idntimes.com/news/indonesia/gregorius-pranandito/ternyata-masih-ada414-hektare-sawah-di-jakarta-ini-sebarannya/3/fullHirch,

Jessen, (2014), diunduh 18 Februari 2021, https://modernfarmer.com/2014/03/floating-farms/ Cilento, K, (2014), 12 Februari 2021, https://www.archdaily.com/59346/hydrogenase-vincentcallebaut?ad_source=search\&ad_medium=search_result_all

Pomeroy, (2019), diunduh 12 Februari 2021, https://www.pomeroystudio.sg/float-farm

Primanita, D. (2015), diunduh 13 Februari 2021, https://www.kompasiana.com/yume_thedreamer/560abf9d4523bd751643bd4d/menujuruang-publik-kota-yang-berkelanjutan?page=all

United Nations, (2015), diunduh 14 Februari 2021, https://www.un.org/sustainabledevelopment/sustainable-development-goals/

Walsh, P, N., (2019), diunduh 12 Februari 2021, https://www.archdaily.com/911677/studionab-designs-a-floating-urban-farming-tower-for-future-

cities?ad_source=search\&ad_medium=search_result_all 
